\title{
Social Pragmatism and Religiosity of Contemporary Russian Youth
}

Tatyana Knyazeva

\author{
Doctor (Psych.), Professor, Head of Department of Classical and Practical Psychology \\ Minin Nizhny Novgorod State Pedagogical University, tnknyazeva@mail.ru
}

\section{Lidiya Semenova}

Doctor (Psych.) Assistant Professor, Professor of Department of Classical and Practical Psychology Minin Nizhny Novgorod State Pedagogical University, verunechka08@list.ru

\section{Anna Chevachina}

Ph.D. (Psych.), Assistant Professor of Department of Classical and Practical Psychology Minin Nizhny Novgorod State Pedagogical University, annochka_v@mail.ru

\section{Doi:10.5901/mjss.2015.v6n6s5p135}

\begin{abstract}
It presents the results of a study aimed at defining the nature of religiosity of students of higher educational institutions and the specifics of relationship of religiosity with regard to pragmatic life goals. The data obtained illustrate the peculiarities in the perceptions of students, differently characterizing their belief in God, about a notion of a true believer, motivation of their countrymen when turning to God, the nature of religion's influence on human beings, as well as circumstances under which interviewed subjects personally turn to God. It is established that most of the Russian youths do not think themselves true believers and express doubts about the existence of true believers, demonstrate with regard to the religiosity of their contemporaries' skepticism and explain the appeal to religion by ignorance, fashion trend and being under human influence of significant others. At the same time, along with their peers, claiming to be true believers, they tend to view religion as a means of consolation and support, and not that of moral perfection and spiritual renewal. In addition, the facts ascertain the presence in true youth believers of egoistic religious motivation and attitude towards God from the standpoint of personal well-being, which suggests their pseudo-religiosity.
\end{abstract}

Keywords: religion, religious consciousness, pseudo-religiosity, pragmatism, Russian youth.

\section{Introduction}

Religiosity as an important characteristic of the consciousness of personality has a significant influence on the behavior and activities of man. The study of various aspects of religious consciousness in modern psychology is important (Dvoinin, 2005; Ugrinovich, 1986). However, the dynamic of processes of socio-historical and socio-political nature in recent years is so global that it cannot but find reflection in the processes of transformation of human consciousness, including its religious aspects.

Religious consciousness is conditional upon acceptance of certain religious ideas and values, and professing oneself as belonging to a certain religion or religious group. In psychological studies, special attention in this respect is paid to the phenomenon of faith in the structure of human psyche (Dvoinin, 2005). Without going into a detailed analysis of various aspects of religious consciousness and psychology of faith, we will note the most significant points in the context of our study.

The psychological phenomenon of faith, defined as the inner relation of man to the world in which the formation of subjective reality takes place (Dvoinin, 2005) is a selective and active/effective component of religious consciousness in general and of religious consciousness in particular. The selectivity of faith (in religious context) is related to the significance of some religious teachings as compared with others. Actively creative nature of faith is motivator for the formation of a particular subjective reality and incentive for taking action in accordance with it. Thus, the effectiveness of faith is rightfully determined by the extent of influence of religious ideas, canons, values, attributes, etc.,adopted by a human being, on his behaviour and activities that is characterized by the concept of "religiosity".

Along with religiosity, psychologists discuss the concept of "pseudo religiosity" ("external religiosity"). Probably, this 
phenomenon is specific for the representatives of various religious trends; however, scientific data is presented, firstly, for respondents belonging to Christianity. In particular, V.A. Matvienko points out: "Professing themselves to be Orthodox, many respondents refer primarily to the origin from the relevant ethno-cultural environment and identify themselves not so much with the Orthodox Church, as with Orthodox cultural tradition. This consideration does not allow to automatically account them among believers" (Matvienko, 2014, p. 328).

Besides, over the last 15-20 years there has been a specific tendency towards fetishism of religious values to achieve purely pragmatic (utilitarian) purposes. In other words, there isa cult not of religious values as such, but of their use (consumption) to meet the pragmatic lifeneeds. Suchtendency, according to some researchers, is devastating: "Consumer attitude towards being is viewed by us as inhumanity in the sense that the essential attributes of man and human activities include not only the moment of appropriation [Aneignung], but also the moment of giving [äußerung]-or rather, their dialectical relationship. Consumerism is totally oriented only on the modus of appropriation. This is very accurately and succinctly expressed in the advertising slogan of Pepsi "Take everything from life" - the true motto of today: not to give, but only to take. This radical and total one-sidedness of human praxis is the lack of authenticity of human-presence-in-the-world, i.e., the inhumanity, and not some elusive degree of human perversity" (Kondrashov and Kruchinina, 2014, p.418).

The origins of this trend are well known, the roots of it go into the theory of social pragmatism (Social Pragmatic Theory), actively developed in American psychology and sociology and based on the theory of the pragmatic philosophy of John Dewey and William James. The essence of the theory is expressed, generally, in a few basic postulates: the standard of moral truth is the feasibility; ethical ideas are accepted as long as they continue to work (Younkins, 2005). The dissemination of ideas of pragmatism on religious consciousness is expressed in the same pragmatic unambiguous approach: it does not matter whether there is God or not, if belief in God makes people happy, He exists; truth is reduced to usefulness, and usefulness is dictated by reality (Johnson, 2015).

The study of Canadian scientists analyzes the psychological facts of influence and application of a pragmatic approach to religiosity on prosocial behavior of people (Norenzayan \& Shariff, 2008). According to the authors, the relationship between religiosity and prosocialityis clearly detected only in those cases where reputation issues move to the forefront: those identifying themselves as believers had the opportunity to demonstrate to God, to themselves and others their high moral fiber. This phenomenon is known among economists, sociologists and psychologists, as conspicuous consumption (llyin, 2000; Harbaugh, 1996; Purinton, 2009).

Features of religious consciousness and behavior of the subjects presented in the above study characterize the subjects belonging to the Western European branch of Christianity. Probably, these features may be due to the specifics of mentality, oriented towards this religious model and type of social behavior. Perhaps other religious trends, forming other values of the religious consciousness and behavior, do not cultivate social pragmatism and conspicuous consumption as psychological components of a person's behaviour? For example, "Russian folklore, describing human desire to achieve positive results, puts communication, "social" over "economic" (Radina et al., 2013).

\section{Research Methods}

In this publication the authors present the analysis of comparative empirical research, allowing to determine the nature of religiosity of contemporary Russian youths and specifics of their correlation of religiosity with pragmatic life goals, and to compare the data obtained with the above global trends, statedby other scientists.

Our study covered students of pedagogical and technical universities in the city of Nizhny Novgorod totaling 106 persons, including 62 females and 44 males 18-22 years old. The study was conducted from May to November 2014.

For the main method of research, we used the problem-oriented interview, including the following issues:

- What kind of a person can you call a true believer?

- Do you consider yourself a true believer? Why?

- What, in your opinion, motivates people to turn to religion?

- What can religion give to a person?

- What is the place of religion in the life of a modern human being?

- When do you think a person usually turns to God, remembers about God?

- Have you addressed God? In what situations?

Interviews' data processing was conducted through open codingprocedures, involving distribution of all responses under meaningful categories. For comparative analysis of data, the criterion $\varphi$ - Fischer angular transformation-was used. 


\section{Results and Discussion}

The first stage of the analysis comprisedof distribution of all subjects into two groups -one of true believers ("A") and those not referring themselves to true believers, to the other one ("B")- based on their answers to the question "Do you consider yourself a true believer?".

Group "A" consisted of 31 persons (29\% of the total number of study participants); group "B" - of 75 persons (71\% of subjects). The following are the specifics of their perceptions of a true believer (Table 1).

Table 1. Perception of a true believer in Russian youths'views

\begin{tabular}{|l|c|c|c|c|c|}
\hline \multicolumn{1}{|c|}{ Subjects } & \multicolumn{2}{c|}{ Group "A" } & \multicolumn{2}{c|}{ Group "B" } & \multirow{2}{*}{ The Fisher Criterion $\left(\varphi^{*}\right)$} \\
\cline { 2 - 5 } & Number & $\%$ & Number & $\%$ & \\
\hline AttendingChurch & 11 & 15,3 & 19 & 15,6 & 0,05 \\
\hline Often addressing God & 10 & 13,9 & 21 & 17,2 & 0,60 \\
\hline Observing religious customs and rituals & 16 & 22,2 & 22 & 18,0 & 0,70 \\
\hline Minister of the Church & 6 & 8,3 & 3 & 2,5 & $\mathbf{1 , 7 9}(\mathbf{p} \leq \mathbf{0 , 0 5})$ \\
\hline Sinless & 6 & 8,3 & 2 & 1,6 & $\mathbf{2 , 2 2}(\mathbf{p} \leq \mathbf{0 , 0 5})$ \\
\hline Selflessly loving God & 11 & 15,3 & 13 & 10,7 & 0,93 \\
\hline Religiously brought up & 6 & 8,3 & 7 & 5,7 & 0,69 \\
\hline Decent and kind & 5 & 7,0 & 11 & 9,0 & 0,49 \\
\hline Elderly & 1 & 1,4 & 11 & 9,0 & $\mathbf{2 , 5 0}(\mathbf{p} \leq \mathbf{0 , 0 1})$ \\
\hline Lack of true believers & - & - & 13 & 10,7 & $\mathbf{4 , 4 8}(\mathbf{p} \leq \mathbf{0 , 0 1})$ \\
\hline
\end{tabular}

From the point of view of young people, attributing themselves to true believers ("A"), a true believer is the one who certainly observes religious rituals, customs and ceremonies, attends Church, sincerely and unselfishly loves God, praises him, and often speaks to him ("hefrequently goes to Church and behaves there appropriately"; "observes fast"; "repents of sins"; "revers God and prays to him," etc.). Almost similar opinion is shared by the subjects, not considering themselves as true believers ("B"), stressing upon strict observance by a believer of religious rites, the fact of his regular communion with God and obligatory attendance at Church ("regularly goes to Church, prays"; "performs all rituals pertinent to certain events"; "turns to his God for advice," etc.).

At the same time, in the answers of respondents from both mentioned groups significantly less mention, as compared with the statements pertaining to the observance of religious canonsby a religious person, was given of his personal qualities and moral deeds relating to interaction with other people and not associated exclusively with religiosity. Thus, messages about decency and kindness of a true believer, and the ones of similar meaning have been seen only in a small number of responses (7\% of the utterances in group "A" and $9 \%$ in group"B")and only in a few instances, recorded statements about sinlessness of a true believer ( $8.3 \%$ in group " $\mathrm{A}$ " and $1.6 \%$ in group "B"). Even true believers from among the subjects made no mention ofresponsiveness, tolerance, compassion, mercy, generosity, etc. of believers.

Overall, we found a pronounced similarity in young people'sviews, differently characterizing their attitude to belief in God, as regards the image of a true believer goes.

Significant differences were established as well: the prevalence in group "A" of a point of view about sinlessness of a true believer $(p \leq 0.05)$ and on the recognition as such of a Minister of Church $(p \leq 0.05)$, and among respondents in group "B" - on a believer being elderly $(p \leq 0.01)$ and manifestation of doubt about the existence of true believers ( $p \leq 0.01)$. It may be noted that the last opinion was not observed amongrespondentsin group "A".

Results of the study of perceptions about the motives behind contemporaries'recourse to religion showed the following (Table 2).

Table 2. Causal attributions of recourse to religion

\begin{tabular}{|l|c|c|c|c|c|}
\hline \multicolumn{1}{|c|}{ Subjects } & \multicolumn{2}{c|}{ Group "A" } & \multicolumn{2}{c|}{ Group "B" } & \multirow{2}{*}{ The Fisher Criterion $\left(\varphi^{*}\right)$} \\
\cline { 2 - 5 } \multicolumn{1}{|c|}{ Categories } & Number & $\%$ & Number & $\%$ & \\
\hline Life hardships & 26 & 22,8 & 22 & 13,7 & $1,94(p \leq 0,05)$ \\
\hline Need for protection, assistance & 18 & 15,8 & 19 & 11,8 & 0,96 \\
\hline Hope for the better & 27 & 23,7 & 22 & 13,7 & $\mathbf{2 , 0 3}(\mathrm{p} \leq 0,05)$ \\
\hline Indecision, uncertainty & 4 & 3,5 & 13 & 8,1 & $1,64(p \leq 0,05)$ \\
\hline
\end{tabular}




\begin{tabular}{|c|c|c|c|c|c|}
\hline Sincere faith in God & 11 & 9,6 & 8 & 5,0 & 1,46 \\
\hline Search for harmony in oneself & 2 & 1,8 & 7 & 4,4 & 1,26 \\
\hline Need for belief & - & - & 6 & 3,6 & $3,12(p \leq 0,01)$ \\
\hline Loneliness & 1 & 0,9 & 6 & 3,6 & 1,57 \\
\hline Social identity & 2 & 1,8 & 7 & 4,4 & 1,26 \\
\hline Disappointment, disillusion in life & 7 & 6,1 & 11 & 6,8 & 0,24 \\
\hline Search for answers & 3 & 2,6 & 2 & 1,2 & 0,85 \\
\hline Fashion & 2 & 1,8 & 9 & 5,6 & $1,71(p \leq 0,05)$ \\
\hline Stupidity & - & - & 4 & 2,5 & $2,60(p \leq 0,01)$ \\
\hline Supernatural, inexplicable situations & 1 & 0,9 & 2 & 1,2 & 0,23 \\
\hline Fear & 3 & 2,6 & 7 & 4,4 & 0,81 \\
\hline Gratitude & 3 & 2,6 & 3 & 1,9 & 0,38 \\
\hline Sins' atonement & 4 & 3,5 & 13 & 8,1 & $1,64(p \leq 0,05)$ \\
\hline
\end{tabular}

Our subjects opined that the main motives behind recourse of people to religion are most often lifehardships, need for assistance and protection and hope for the better.In the majority of cases, this opinion was shared by respondents from group "A" (reliably significant differences by categories "life hardships" and "hope for the better" at the level $p \leq 0.05$ ). Respondents in group "B" more frequently cited the following reasons: indecision and uncertainty of man, his weakness (reliably significant differences in their favor at the level $p \leq 0.05$ ); fashion for religion and everything associated with it, including Church rituals and attributes (differences in their favor at the level $p \leq 0.05$ ); need for atonement (differences in their favor at the level $p \leq 0.05$ ); need for belief and human stupidity (in both categories,reliably significant differences in their favor at the level $p \leq 0,01$ ). Especially we would like to emphasize that in the last two instances we are talking about responses that had no mention in the other tested group at all.

As an illustration let us quote some sayings of the respondents of group "B": "Today it has become fashionable to wear crosses, to buy icons. Many people do this just because it should be this way, since so many others do it. This allows them to be within a so called trend." "Only stupid people can believe in and hope for help from something supernatural", etc.

Subjects in group "B" more frequently named such reasons as loneliness, fear, a sense of belonging to a meaningful group and search for harmony in oneself, whereas the subjects that professed themselves as true believers, a little more often cited a sense of gratitude. However, all these differences are negligible and feedbacks of this kind are mainly episodic.

The striking coincidence of respondents'viewsin groups "A" and "B", the quantitative ratio of which is recorded in Table 3, is most evident when tracing the answers to the question as to what precisely can be given by religion to a human being.

Table 3. Semantic interpretation of religion's influence on man

\begin{tabular}{|l|c|c|c|c|c|}
\hline \multicolumn{1}{|c|}{ Subjects } & \multicolumn{2}{c|}{ Group "A" } & \multicolumn{2}{c|}{ Group "B" } & \multirow{2}{*}{ The Fisher Criterion $\left(\varphi^{\star}\right)$} \\
\cline { 2 - 5 } & Number & $\%$ & Number & $\%$ & \\
\hline Help and support & 24 & 24,7 & 27 & 21,8 & 0,50 \\
\hline Confidence and peace of mind & 27 & 27,8 & 31 & 25,0 & 0,47 \\
\hline Ability to believe & 9 & 9,3 & 7 & 5,6 & 1,05 \\
\hline Inner peace harmony and perfection in spiritual realm & 11 & 11,3 & 8 & 6,5 & 1,25 \\
\hline Purpose and life meaning & 9 & 9,3 & 6 & 4,8 & 1,31 \\
\hline Faith in people and relationships & 2 & 2,1 & 5 & 4,0 & 0,83 \\
\hline Misconceptions and prejudices & - & - & 11 & 8,9 & $\mathbf{4 , 4 7}(\mathbf{p} \leq \mathbf{0 , 0 1})$ \\
\hline Answers to various questions & 4 & 4,1 & 9 & 7,3 & 1,03 \\
\hline Self-justification & - & - & 9 & 7,3 & $\mathbf{4 , 0 4}(\mathbf{p} \leq \mathbf{0 , 0 1})$ \\
\hline Strength & 3 & 3,1 & 7 & 5,6 & 0,92 \\
\hline Salvation & 5 & 5,2 & - & - & $\mathbf{3 , 4 0}(\mathbf{p} \leq \mathbf{0 , 0 1 )}$ \\
\hline Fear of God & 3 & 3,1 & 4 & 3,2 & $\mathbf{0 , 0 4}$ \\
\hline
\end{tabular}

According to the data received, the vast majority of youths tend to believe that religion makes people more confident and calm, gives them help and support they need. It is such responses that were most common in both groups of subjects. Besides, noteworthy is a point of view that religion and faith can give people strength, provide answers to various 
questions, give purpose and meaning in life, confidence in people, on the one hand, and fear of God, on the other.

At the same time, we found reliably significant differences. In particular, the subjects in group"B" were sure that religion leads to prejudice $(p \leq 0.01)$ and allows a person to engage in self-justification, praying to exonerate his sins $(p \leq 0.01)$. On the contrary, among the respondents in group " $A$ " we saw a different opinion-the possibility to attain salvation through religion $(\mathrm{p} \leq 0.01)$.

Answering the question about the place of religion in modern life, respondents of group "A" stressed primary role of religion in modern society, insisted on the fact of its revival in the Russian state, while the subjects in group "B" talked about the pragmatism of their countrymen and contemporaries, about the loss of popularity of religion in the twenty-first century.

The opinions of the respondents about the conditions and situations, in which a person usually turns to God, are presented in Table 4.

Table 4. Attribution of situations and conditions for turning to God

\begin{tabular}{|l|c|c|c|c|c|}
\hline \multicolumn{1}{|c|}{ Subjects } & \multicolumn{2}{c|}{ Group "A" } & \multicolumn{2}{c|}{ Group "B" } & \multirow{2}{*}{ The Fisher Criterion $\left(\varphi^{*}\right)$} \\
\cline { 2 - 5 } \multicolumn{1}{c|}{ Categories } & 21 & 27,6 & 47 & 32,9 & 0,82 \\
\hline Despair, God as the last hope only & 26 & 34,2 & 41 & 28,7 & 0,83 \\
\hline Life difficulties & 18 & 23,7 & 33 & 23,0 & 0,12 \\
\hline Appeals for assistance and protection & 4 & 5,3 & 3 & 2,1 & 1,22 \\
\hline Gratitude & 6 & 7,9 & 5 & 3,5 & 1,37 \\
\hline Joy experiences, life happy moments & 1 & 1,3 & 9 & 6,3 & $\mathbf{1 , 9 6 ( p \leq 0 , 0 5 )}$ \\
\hline Religious holidays and traditions & - & - & 4 & 2,8 & $\mathbf{2 , 3 7}(\mathbf{p} \leq \mathbf{0 , 0 1})$ \\
\hline Solidarity with others & - & - & 1 & 0,7 & 1,18 \\
\hline Blaming God & & & & & \\
\hline
\end{tabular}

The predominant type of attribution in both groups of subjects is the focus on hardshipspeople face in life and their feeling of the sense of despair, when God remains the last hope: "God is usually remembered in desperate situations, when one feels hopelessness and despair. Then God is the last hope" (group "B"); "We should appeal to God only in extreme cases when it is quite clear that without Him we will not manage" (group "A").

At the same time, in the nature of attribution of situations and conditions forturning to God, between the groups, there is a number of statistically significant differences and all of them are in favor of the respondents in group "B". So, it is the latter who tend to show a view of the close ties between turning to God with religious holidays and traditions $(p \leq 0.01)$, and also name solidarity with other significant people $(p \leq 0.01)$ as a possible reason for the human need for God.

"If a person is raised religious, then, of course, he will commune with God on all religious holidays. It is his habit now. And the earlieritis acquired, the more likely that he will continue doing it". "Many do not do it by their own choice, but simply because othersdoso. This is something like conformity, I would say. The desire not to be black sheep. Demonstration of belonging and loyalty to those who, for whatever reason, are important."

In the context of the studied problem especially interesting is the answer to the last question of the interview, pertaining to the fact itself and personal circumstances of youth turning to God.

Despite the fact that only a small part of our respondents identified themselves as true believers, the subjects of both groups reported that they too, during their life span, turned to God, namely: $82.3 \%$ of girls (numbering 51) and $77.3 \%$ of boys (34). Moreover, they comprised all our subjects from group "A" and $72 \%$ of the tested subjects from group "B". (Table 5).

Overall, according to our survey participants, their turning to God took placeunder the following circumstances

Table 5. Circumstances for Russian youths' personal turning to God

\begin{tabular}{|l|c|c|c|c|c|}
\hline \multirow{2}{*}{ Subjects } & \multicolumn{2}{|c|}{ Group "A" } & \multicolumn{2}{c|}{ Group "B" } & \multirow{2}{*}{ The Fisher Criterion $\left(\varphi^{*}\right)$} \\
\cline { 2 - 5 } \multicolumn{1}{c|}{ Categories } & Number & $\%$ & Number & $\%$ & \\
\hline Life hardships & 17 & 43,6 & 29 & 43,9 & 0,03 \\
\hline Hopelessness & 8 & 20,5 & 11 & 16,7 & 0,49 \\
\hline
\end{tabular}




\begin{tabular}{|l|c|c|c|c|c|}
\hline Pleading for help to oneself & 6 & 15,3 & 11 & 16,7 & 0,19 \\
\hline Pleading for help to dear ones & 2 & 5,2 & 5 & 7,6 & 0,50 \\
\hline Gratitude & 5 & 12,8 & 9 & 13,6 & 0,12 \\
\hline Question & 1 & 2,6 & 1 & 1,5 & 0.39 \\
\hline
\end{tabular}

As can be seen from Table 5, no significant differences are observed in the reported circumstances for personal appeal to God by the subjects of groups "A" and "B". All of them, almost equally, mention life hardships and situations that cause a feeling of hopelessness, but mostly speak about help for themselves than to others. It may be noted that the latter allows us to consider religious motivation of today's youths (even those that plead to be true believers) asselfish rather than altruistic, consonant with the pragmatic values of personal well-being.

\section{Conclusion}

The data obtained allow concluding the following.

The nature of subjective perceptions of contemporary youths about religion and the reasons for recourse to it, on the one hand, is partly due to the personal commitment of young generation to faith in God, and, on the other hand, demonstrates general trends of modern post-industrial society, thathas actualized pragmatic values and orients young people predominantly on the mode of appropriation and consumption.

The fact of professing oneselfas a true believer, all by itself, doesnot give much impetus to orientation of today's Russian youths on moral and prosocial behavior, selflessness, and humanism,rather, professing oneself as a believer simply constructs specific requirement in God as an assistant in solving vital problems, sometimes with very distinctly expressed egoistic interests. The majority of young females and males views God and faith in Himin the context of personal well-being, and recourse to religion at the level of motivation is reduced to the logic of utility.

Young people who do not consider themselves true believers, when speaking out from the standpoint of pragmatic approach, express doubts in the existence of true believers, demonstrate skepticism regarding religiosity of their contemporary compatriots, associate recourse to religion with ignorance, fashion and influence,exerted on a person by significant others, and attribute to religion properthe function of disseminating delusions and self-justification.

Regardless of the fact whether young people consider themselves true believers or not, the absolute majority of them has a prevailing view about the propensity of people to seek in religion a means of comfort and support, capability of religion to give people hope and peace of mind, i.e. the fulfilment by religion of the functions of protection and support, but not of a moral, spiritual revival of society.

In other words, despite quite active propaganda in the promotion of religion and participation of religious figures in secular life of modern Russia, a significant part of young students is pseudo religious and considers religion and faith in God primarily in the context of pragmatic values and personal well-being.

\section{References}

Dvoinin, A. (2005). Psychological study of faith phenomenon. Jornal of Development of personality, 2,96-111.

Harbaugh, R. (1996). Falling behind the Joneses Relative consumption growth and the saving paradox. Journal of Economic Letters, 53.

Hicks, D.L. \& Hicks, J.H. (2012). Jealous of the Joneses: Conspicuous Consumption, Inequality, and Crime. [Online] Available: http://ssrn.com/abstract=2164456 or http://dx.doi.org/10.2139/ssrn.2164456 (Sept. 1, 2012).

Ilyin, V.I. (2000). Behaviour of consumers. St. Petersburg: Izdatel'stvo Piter.

Johnson, W. (2015). Social Pragmatic Theory.[Online] Available: http://www.ehow.com/about_5533947_social-pragmatic-theory.html (Sept. 6, 2015).

Kondrashov, P.N.,Kruchinina, A.V. (2014). Total focus on possession and consumption [Social ontology in the structures of theoretical knowledge]. Izhevsk.

Matvienko, V.A. (2014). Constructing religious identity in the context of social activity of the Russian Orthodox Church in modern Russia[Social ontology in the structures of theoretical knowledge]. Izhevsk.

Norenzayan, A., Shariff, Azim F. (2008). The Origin and Evolution of Religious Prosociality. Journal of Science, 322, 58-62.

Purinton, E.F. (2009). Compensatory Or Conspicuous Consumption? Bling It On, American Society of Business and Behavioral Sciences 16th Annual Conference. Vol. 16.

Radina, N.K., Shaidakova, N.V., Mokhnatkina, I.N. (2013). Conspicuous consumption of today's adolescents: social-psychological factors.Journal of Social psychology and society, 1, 52-66.

Ugrinovich, D.M. (1986). Psychology of religion. Moskva: Izdatel'stvoPolitizdat.

Younkins, E.W. (2005). Dewey's Pragmatism and the Decline of Education. [Online] Available: http://rebirthofreason.com/Articles/ Younkins/Deweys_Pragmatism_and_the_Decline_of_Education.shtml (Sept. 29, 2005). 